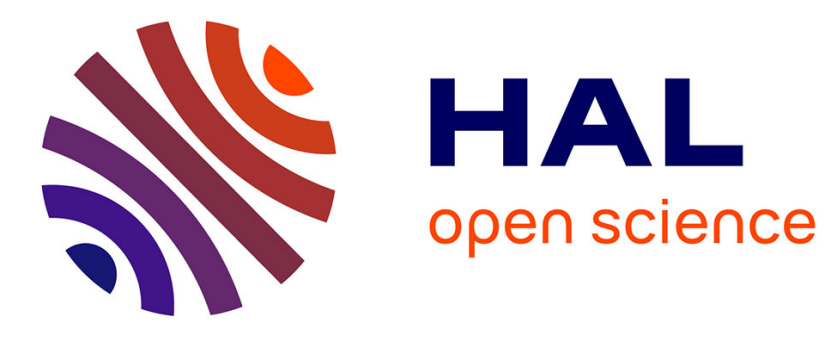

\title{
How broadening social connections changes farmers' conceptions about biodiversity.
}

\author{
Bertille Thareau, Clara Pailleux, Guilhem Anzalone
}

\section{To cite this version:}

Bertille Thareau, Clara Pailleux, Guilhem Anzalone. How broadening social connections changes farmers' conceptions about biodiversity.: Multiple links to biodiversity explored through the different socioprofessional paths of farmers. Review of Agricultural, Food and Environmental Studies, 2020, 101 (2-3), pp.241-259. 10.1007/s41130-020-00104-0 . hal-03195642

\section{HAL Id: hal-03195642 \\ https://hal.science/hal-03195642}

Submitted on 12 Apr 2021

HAL is a multi-disciplinary open access archive for the deposit and dissemination of scientific research documents, whether they are published or not. The documents may come from teaching and research institutions in France or abroad, or from public or private research centers.
L'archive ouverte pluridisciplinaire HAL, est destinée au dépôt et à la diffusion de documents scientifiques de niveau recherche, publiés ou non, émanant des établissements d'enseignement et de recherche français ou étrangers, des laboratoires publics ou privés. 


\title{
How broadening social connections changes farmers' conceptions about biodiversity.
}

\section{Multiple links to biodiversity explored through the different socioprofessional paths of farmers}

\author{
Bertille Thareau $^{1}$ (D) $\cdot$ Clara Pailleux $^{1} \cdot$ Guilhem Anzalone $^{1}$ (D)
}

Received: 1 February 2019 / Accepted: 18 March 2020/ Published online: 8 April 2020

(C) INRAE and Springer-Verlag France SAS, part of Springer Nature 2020

\begin{abstract}
The relationship between agriculture and biodiversity divides opinion among farmers. Our research proposes to describe and interpret these opinions, with regard to the diversity of the social backgrounds of the producers, with the hypothesis that interactions with local, non-agricultural individuals help shape these opinions. From 14 interviews carried out with farmers engaged in actions to preserve biodiversity in three territories in the West of France, we identify four different occupational conceptions, characterized by knowledge and taking natural entities into account, through the values and vision of the role that farmers intend to play with regard to biodiversity and way in which they would like this issue to be handled by society. While the role of peer networks in the construction of job conceptions is well established, our research shows that understanding the attitudes of agricultural professionals today requires a consideration of the role that experience and interactions with those outside the agricultural professional sphere play.
\end{abstract}

Keywords Occupational conception · Socio-professional path · Agro-ecology · Social network $\cdot$ Professional knowledge

\section{Introduction}

Diversification of farming approaches is no longer an issue that needs to be questioned. In France, numerous studies have highlighted the emergence, alongside the long-

Clara Pailleux contributed equally to this work.

Bertille Thareau

b.thareau@groupe-esa.com

1 LARESS, Ecole Supérieure d'Agricultures (ESA), 55 rue Rabelais, 49000 Angers, France 
dominant model of family farming, of forms of peasant, sustainable, organic or firm farming (Hervieu and Purseigle 2015). This diversification reflects a reorganization of agricultural business structures, work collectives, modes of farm transmission and farming profession, practices, but also conceptions of desirable ways of farming. We propose that these conceptions allow definition of professional models, understood as 'a set of standards associated with values - linked to a certain conception of their roles and functions - allowing farmers to situate themselves in the professional agricultural field and within society. This constitutes a frame of thought for both 'what to do' and 'how to do it" (Candau and Ruault 2005).

\section{Socio-professional backgrounds, central to farmers' conceptions of their profession}

The construction of professional conceptions operates over time and in the context of interactions with peers and other categories of actors. We propose to link an analysis of professional conceptions to a study of the socio-professional paths of farmers - defined as successions of social relationships taken from both a diachronic and synchronic perspective (Bourdieu 1986).

The understanding of a profession is based, in part, on a process of professional socialization that, often in agriculture, begins in early childhood as part of the parental education because, in farming families, the trade is often passed on to the children. In $2015,81 \%$ of French male farmers between the ages of 30 and 59 were, themselves, children of farmers. ${ }^{1}$ This process of passing on the trade participates to the reproduction of inherited agricultural models. However, the profiles of farm managers are changing: there are more and more intra/extra-agricultural 'changes of profession' (Dubuisson-Quellier and Giraud 2010) and the number of non-familial farms is increasing. In addition, the weight of the farming family is questioned (Pibou 2013) prompting the discussion of the role of the family institution in the transmission of modes of thought and knowledge (Jacques-Jouvenot and Gillet 2001; Joosse and Grubbström 2017). The example of organic farmers is striking: the heterogeneity of their biographical situations - parents' occupations, prior professional activities, schooling, prior social engagements - leads to a diversity of understandings of organic agriculture, consumer relations and relational practices more generally (Van Dam 2005). The use of biographical background therefore allows us to identify the paths during which conceptions are constructed.

Additionally, socio-professional networks are central to the development of farming culture. Interaction within the local occupational group promotes a collective development between farmers of a local, technical culture (Barbier and Lemery 2000; Compagnone and Hellec 2015).

However, these cognitive processes are also marked by social attachments and detachments (Goulet and Vinck 2012) and by moments of social openness that involve taking into account, in particular, the role of territorial players, who participate to the evolution of productive systems (Lamine 2011). With the process of social openness underway for the past twenty years, a plurality of non-agricultural actors (consumers, locally elected officials, managers of natural spaces, environmental associations) are now participating, temporarily or continuously, to the debate (Ruault and Soulard

$\overline{{ }^{1} \text { Insee, enquête FQP 2014-2015 }}$ 
2015). Depending on how the farmer interacts with non-agricultural players in the course of his professional activity, he experiences different representations of the territory or perceptions of the multi-functionality of agriculture (Dufour et al. 2007). It is also during mixed debate that different categories of knowledge come into play and that a reconfiguration of farmers' professional models takes place. The work of Candau and Ruault (2005) shows that the professional models of farmers who are primarily holders of technical knowledge evolve given contact with environmental experts offering naturalistic knowledge. To the extent that socio-professional relations are bound to renew themselves, these conceptions are not fixed: this is shown by Dufour et al. (2016) by increasing their study of process analysis networks and demonstrating that the meaning of commitment to organic farming evolves over the course of an organic farmer's career.

\section{From a process of distinction of the 'conventional' model to an issue of characterization of contemporary agricultural models}

While the diversity of farmers' social situations and engagements contributes to a diversity of views of the trade, this process cannot be understood independently from a segmentation movement of the agricultural profession. For the past forty years, professional groups have been structured and institutionalized. These farming models most often cover approaches positioned as alternative to the dominant model, which has the effect of homogenizing so-called conventional agriculture without denoting what brings these alternatives together. Many of these groups claim a form of agroecology. However, definitions of agro-ecology are numerous and heterogeneous. A plurality of actors associate it with their own values and compete to define its contours and recognition. While Agro-ecology had become a watchword carried by the Ministry of Agriculture, in 2013 a consortium of naturalist organizations described it as 'local agriculture creating employment, within a social economy, and is a factor of territorial viability, essential for diverse, fresh products for the townspeople'. ${ }^{2}$ But in 2014, the law for the future of agriculture proposed a very broad framework for agro-ecology: 'These systems favor the autonomy of agricultural holdings and the improvement of their competitiveness, by maintaining or increasing economic profitability, by improving the added value of production and reducing the consumption of energy, water, fertilizers, plant protection products and veterinary drugs, in particular antibiotics. They are based on biological interactions, the use of ecosystem services and potentials offered by natural resources, in particular water resources, biodiversity, photosynthesis, soil and air, while maintaining their capacity to renew the qualitative and quantitative point of view, ${ }^{3}$ The legislator takes care to promote forms of innovation and experimentation encouraging diverse readings of this concept. The underlying agricultural models should therefore be more precisely characterized. With this in mind, several studies propose a general typology of agro-ecology principles and categories of practices (Plumecocq et al. 2018; Wezel and Peeters 2014). Others highlight a plurality of world views and analyse their place in the agro-ecological transition. When they

\footnotetext{
${ }^{2}$ Nature et Progrès' Open letter (co-signed by 20 associations) for the attention of the Agriculture Minister, 22nd January 2013.

${ }^{3}$ Law no. 2014-1170, 13th October 2014 'd'avenir pour l'agriculture, l'alimentation et la forêt'.
} 
focus on characterizing farmers' representations based on empirical data, they emphasize their diversity (also at an intra-individual level), but do not describe their social anchoring (Cayre et al. 2018).

Our research proposes to account for farmers' understandings of their trade, and to interpret them in view of the diversity of their social backgrounds. We explore the hypothesis that interactions with non-agricultural actors at the territorial level contribute to building this knowledge and representations, and that social configurations are therefore a matter of importance that marks career paths. In order to do this, we surveyed a selected population of farmers involved in biodiversity and conservation, all associated with the same environmental association (the LPO, League for the Protection of Birds). These farmers are designated as agro-ecologists by this association, which is itself committed to promoting green farming. ${ }^{4}$ In doing so, we agreed to contribute to the characterization, profiling and better understanding of their farmer members. The LPO assumed that we would succeed in describing a significant number of common traits within this singular population, and therefore in helping to define an 'agricultural model' (already designated as 'paysan de nature'-_Farmer of Nature') with the intention of promoting it at an exhibition of the same name, displaying the project results.

\section{Investigation area and methods}

\section{We report on the uniqueness and diversity of professional models based on the relationship of farmers to biodiversity}

Our research is part of a project with the objective of accounting for the development conditions of agro-ecological dynamics at a territorial scale. We sought in particular to study the role of informal social dynamics. To do this, we identified farmers involved to varying degrees with the Bird Protection League (LPO) in a region in western France, the Pays de la Loire.

The question of biodiversity constitutes a relevant boundary object for exploring the effects of the social opening of fields of work and dialogues for farmers about the evolution of their conceptions and knowledge. Biodiversity is indeed a subject on which non-agricultural players are invited to participate in debate set up in the territories (Candau and Ruault 2005; Thareau et al. 2016). Additionally, biodiversity is an object which questions both sensitive and practical relationships with plants and animals, which conveys a large amount of knowledge on ecological processes today, and which is reflected in attempts to build rules for management or production standards, therefore questioning the relationships of farmers to the common good and to the State. This triple quality of biodiversity is qualified by André Micoud through the notions of percept, concept and precept (Micoud 2005). In this particular context of farmers associated with ecological projects, understanding farmers' relationships with

\footnotetext{
${ }^{4}$ In 2012, the LPO edited a « manifesto for an agriculture in respect of Nature and Humanity » in which agroecology is cited as a way to promote (https:/www.lpo.fr/images/actualites/2012/Manifeste). In 2013, the LPO is signatory of Nature et progrès' open letter previously mentioned.
} 
biodiversity allows questions about the different dimensions (sensitive and material, cognitive, social) which shape different forms of professionalism.

Our research focused on relationships between conceptions of the profession and the social context of farmers during their socio-professional path, putting aside the analysis of practices and their evolution, which is well documented in other works (Cayre et al. 2018; Lamine 2011; Plumecocq et al. 2018). We sought to describe and decompose the conceptions that farmers have of the relationships between biodiversity and agriculture by taking inspiration from the conceptual framework of worldviews by Hedlund, who describes 5 dimensions: ontological, epistemological, axiological, anthropological and finally societal (Hedlund-de Witt 2013). Our research intends to highlight and deepen the analysis of the entities taken into account and the information used by farmers to understand biodiversity (ontological and epistemological dimensions), values, opinions of what needs to be done and the role that farmers take on regarding biodiversity (axiological and anthropological) and finally, their representation of the way in which society should organize the links between agriculture and societal biodiversity.

\section{Sampling: farmers and diverse territories}

We surveyed 14 farmers selected, with the support of the LPO, among the farmers participating in the association's network (members) and/or contributing to activities carried out by the LPO (conducting biodiversity surveys/monitoring, activities for the general public, joint collaboration in programs to protect important species). A large part of them practiced polyculture-breeding systems (mostly suckling cows). We sampled profiles differentiated by their setup conditions ( 5 had taken over the family farm, 4 were from the agricultural sector but had set up independently from their family and 5 were not from an agricultural background), the point in their career, their age (7 were under 40, 4 between 40 and 55 years old and 3 over 55 years old), and their product labelling ('Nature et progrès', Organic or none). Some worked as a couple and in some cases the spouses were able to join the interview, but not systematically.

We chose to investigate three areas, presenting contrasting associative and local dynamics. The areas, located in two departments: Maine et Loire and Vendée, were Anjou (in Maine and Loire), the Marais Breton Vendéen and the bocage Yonnais (in Vendée). These areas are characterized by particular social dynamics.

Firstly, the departmental structures of the LPO do not adopt the same attitude regarding the promotion of agro-ecology. The LPO in Vendée removes any farmer who does not realign his occupational conceptions around their principles of territorial governance. This implies in particular, commitment to local consumer and naturalist social networks and distancing from conventional professional institutions. The LPO in Maine et Loire accepts more 'traditional' professional spheres, aiming for a gradual change of practices towards agro-ecology. The Maine et Loire has had a tradition of dialogue between farmers and naturalists for several decades (Le Guen and Sigwalt 1999) and territorial non-professional actors (LPO, Chamber of Agriculture) work together for the protection of wetlands.

Groups of farmers from Anjou and Marais Breton Vendéen (respectively 'Eleveurs des Vallées Angevines' and 'Gens du Marais et d'ailleurs') are both engaged in communication to demonstrate their commitment to promoting biodiversity. However, their strategy is changing: the former organize their communication through a brand 
while the latter meet consumers at farmers' markets. At the same time, consumer organizations are structured differently. While community-supported agriculture (CSA) are very numerous in le bocage Yonnais and in Anjou, they are replaced in Marais Breton Vendéen by a specific organization: 'Collectif Court Circuit' which is, in addition to a source of food, a space to raise awareness about the challenges of the agriculture of tomorrow and opportunities for citizen involvement (campaigns to mobilize citizens etc.).

Despite their differences, all three of the study territories present local social configurations marked by their commitment to the LPO: actions associating local farmers, and forms of consumer mobilization around sustainable food. The LPO is also involved in a regional project, promoting a form of green agriculture, which they seek to qualify and define around the slogan 'Paysans de Nature' (Farmers of Nature). It is structured around three activities: technical support for the development of agricultural practices favourable to the maintenance of biodiversity, the promotion of 'Paysans de Nature' to citizens and young people through educational environmental activities, and finally, support for producers at key moments in their career (setting up, access to land, training, development of outlets etc.). However, if the association has developed activities and recognized expertise regarding the first two parts of this project, it is less aware of the profiles and socio-professional paths of the farmers involved with it and wishes to base the development of its support activities for farmers on better knowledge of this professional group. Our research contributes to this via the joint description of the occupational conceptions and the socio-professional paths of the farmers associated with the LPO. In this context, the definition of the survey sample was, not surprisingly, the occasion for debate between the association and the researchers. The first seeks to tighten the investigation around farmers, which they perceive as exemplary situations of the agricultural model, which it wishes to promote, the second aim to reflect the diversity of farmers engaged alongside the association. It can be seen that our sample is structured by the LPO, in the sense that all the respondents interact with the association; however, the farmers we surveyed were involved in different ways (active in different areas, activities related to the association with varying intensity, members, or not, of the association). We will specifically discuss, at the end of this paper, the role of the association in defining and prioritizing professional models identified within this group.

\section{Bifurcations: key moments to identify the role of non-agricultural actors}

Our analytical framework is based on the work of Bidart et al. (2013) relating to biographical bifurcations. At these precise moments, interactions constitute social resources for problem solving. We did not limit ourselves to the study of strictly cognitive interactions, and consider that any type of interaction-observed at the precise moment of change-participates to the development of how the trade is understood.

From semi-structured interviews, lasting an average of an hour and a half, we collected the life stories of these farmers. The interviews, carried out applying rules of the biographical method, were processed and revealed 'practical knowledge' (Bertaux 1997) and 'life experiences' (Dubar et al. 2015) responsible for socioprofessional paths. The life stories exposed the meaning that the interviewee gave to 
his actions (Chaxel et al. 2014). Respondents were first asked to tell their story: "the events in your personal and professional life that led you to have this sensitivity for the environment'. From this story, they were invited to contextualize, evaluate and explain the changes experienced. This survey system allows reflection on the construction of farming conceptions linked to biodiversity. It provides elements for describing socioprofessional paths and allows joint analysis of interactions with non-agricultural actors and the construction of conceptions of the trade, and particularly the representations of the role of biodiversity in agricultural activities.

Analysis of the farmer's occupational conceptions revealed heterogeneity. These conceptions are associated with uncommon socio-professional paths. Our analysis is therefore structured around the construction of a typology which highlights four modeltypes of farmers. Four dimensions were retained for this categorization work: the three components of job conceptions inspired by Hedlund-de Witt (2013) (the entities taken into account and the types of knowledge applied by farmers to understand biodiversity; values, evaluating what ought to be done and the role that farmers take on regarding biodiversity; their representation of how society should organize links between agriculture and biodiversity) as well as the characterization of career paths (parents' profession, training, professional experiences before setting up, difficulties encountered in an agricultural context and the social resources put together to overcome them).

\section{Coexistence of occupational conceptions constructed during socio-professional paths}

Categorization work led to four distinct types of farmer, which we named: 'protector of natural areas', 'dissident farmer', 'producer under environmental contract' and 'neorural farmer'. Between two and five farmers falling into each category.

\section{The 'protector of natural spaces'}

This type of farmer demonstrates a strong desire to conserve biodiversity on his farm, in particular the intrinsic qualities of the breeds or varieties he breeds or cultivates. Often, he positions himself as a 'background' member of the ecosystem to which he belongs. Agriculture here serves to preserve and develop a wild and exceptional biodiversity, which has value in itself. In other words, agriculture becomes a support facilitating the preservation of biodiversity: raising livestock to maintain land with notable specificities, reserving land to ensure the ecological treatment of natural spaces (offering sites for breeding, rest for migrators etc.). This conception of the trade is not limited to the farm. Agriculture is perceived as managing a set of habitats which, once connected, create ecological corridors. The place of biodiversity in agriculture is therefore central to this occupational conception.

This type of farmer has a deep knowledge of the natural sciences, such as ornithology or botany (hereafter referred to as 'naturalist knowledge'), and of ecological science ('ecological knowledge'). These categories of knowledge allow the farmer to assess how his ecosystem functions, to make an inventory and to study all the living

\footnotetext{
5 Three surveys are associated with this type.
} 
things present on his land. This is evident in the words of one farmer who, having set up cofferdams allowing water to be kept in low plots, observes species, which he easily recognizes, returning to their habitat:

'I stopped it up last winter. This spring it's crazy. It's like a nature reserve! A couple of lapwings, gambets. There are a couple of ruffs parading around, a couple of teals, a couple of gadwalls ... '(farmer, 36 years old, Marais Breton Vendéen)

This understanding of biodiversity is built into the socio-professional path of the 'protector of natural spaces'. He's not from an agricultural or even rural background, as he comes from an urban environment. He has a higher education in biological studies, a Masters level, which distinguishes him from farmers in other categories. He begins his career with work placements or paid professional experience in associations for the protection of biodiversity (LPO). It is at this time, in contact with volunteers and employees, that he studies ornithology; later this will strongly mark his conceptions of farming. As part of his work, he also comes into contact with the agricultural world (agro-environmental missions). When he decides to settle, the difficulties he has to overcome are economic and material: finding land, investing in production equipment, and building a sales channel. It's his local social capital-from his time as an association employee - which leads to help from the local authorities or associations (naturalists, farmer startups) to acquire the land and resources necessary to quickly establish himself on the consumer market in short circuits. ${ }^{6}$ His wife often works in areas related to land planning and the environment.

As a 'non-agricultural worker' before settling down, he continues to assert his desire for proximity with consumers, nature reserve managers and locally elected officials because he thinks of his agro-ecology project as part of a territorial project. This type of farmer is particular in having a more accomplished agro-ecology project than the nonagricultural actors themselves. He sets up educational strategies (biodiversity outings on the farm) to bridge this gap and involve territorial actors in shaping the agriculture of tomorrow. $^{7}$ This type of farmer seeks to shrug off the organic label, which he accuses of lowering specification requirements with cumbersome, nonsensical administration. He is also very critical of conventional agriculture, 'traditional' development organizations (which he deems incompetent) and the majority union, which slows down the transition of territories to agro-ecology (blocking access to land for some farmers, criticizing the environmental efficiency of agro-environmental and climate measures).

This type of farmer is in close contact with non-agricultural actors (and conversely, distant from traditional professional actors). Environmental actors participate in the construction of what will form the basis of the farmer's occupational conception, before his setting up. By encouraging setting up, consumers and locally elected officials also contribute to shaping perceptions of an agro-ecology that breaks down the boundaries

\footnotetext{
${ }^{6}$ The naturalistic and environmental knowledge he has previously built assures him recognition from nonagricultural actors.

${ }^{7}$ This type of farmer has an interest in encouraging strong societal requirements, as long as his agro-ecology project would benefit. At the forefront of agro-ecology claiming the importance of new modes of governance, it is sure to capture territorial resources available to support the transition to agro-ecology if such a definition were chosen.
} 
between professionals and non-professionals. These interactions continue afterwards (post setting up period) but they evolve in the sense that the farmer, by occupying positions of responsibility in local associations, tends to become a 'knowledge broker' of agro-ecology principles for territorial actors.

\section{The 'dissident farmer'}

This type of farmer is primarily interested in the biodiversity cultivated on his farm. Old breeds are appreciated for their adaptation to the area but must nevertheless meet production objectives (prolificity, quantity of meat). This 'professional' seeks a balanced relationship with nature: he bases his activity on working the soil and natural resources, but he wishes to regain a sense of humility - similar to that which he believes once linked the farmer to his land-which would ensure that his practices have a limited impact on the environment. Agriculture serves first and foremost to preserve domestic biodiversity composed of ancient breeds and varieties, disappearing in the standardization of living things. Agriculture also contributes to the preservation of auxiliary biodiversity, now endangered by the ravages of phytosanitary products and, more generally, by the generalization of industrial and productivist agriculture. Finally, agriculture ensures the maintenance of a biodiversity of commensal, threatened or endangered species. In this way, agriculture helps regain a rich and diversified biodiversity at farm level.

This type of farmer's perception of biodiversity is therefore intimately linked to the professional activity. He becomes a pilot of nature, accompanying her to keep her from harm. We call this mixture of agronomy and practical knowledge of the farming system, 'agrosystemic' knowledge. This is illustrated by the testimony of the following farmer, who relates his first non-ploughing trials:

'It's not just by snaping our fingers that we can bring the earthworms back, increase the rate of organic matter or return to a natural nitrogen cycle'. (Farmer, 40 years old, Anjou)

This type of farmer shows an interest in naturalist knowledge (as defined above), but has difficulty translating this type of knowledge into practice:

'Sometimes in the summer, when there's not much grass and I'm using hay, the plot next door might have a little grass... but it shouldn't be used, for ecological reasons. At first, that's hard! But then, what can you do?' (farmer, Marais Breton Vendéen)

This can be explained by the 'dissident farmer's' socio-professional path. He is a farmer's son who inherited a productivist agricultural culture. This is also the case of his wife, with whom he has settled. After an educational path specializing in agriculture (BTS-2-year vocational degree), he continues in the same sector (manual labour). ${ }^{9}$ At this stage, as a result of limited socio-professional exposure along his path, it's easy to

\footnotetext{
${ }^{8}$ Five surveys are associated with this type.

${ }^{9}$ Some farmers of this type settled directly after their studies.
} 
understand why he turns towards his professional agricultural knowledge. This type of farmer also stands out for having - very early in his path (at around 20 years old) participated in militant efforts on cross-cutting issues such as culture, the environment or social issues. Although he sets up as a conventional farmer in the 1980s, outside the family framework, he gradually moves towards organic farming. The conversion begins at the turn of the 2000s thanks to frequent and repeated contact (at militant events) with local actors (agricultural professionals or otherwise) from the agro-ecology movement (militant- organic neighbours, nearby naturalist networks).

These social links help old, conventional networks to be shed and allow ecological learning that reinforces the detachment from old ways of thinking and practising agriculture (technical information removing uncertainties, scientific information helping grasp the nature of the stakes etc.). In this case, conversion to organic agriculture leads to a broader recomposition of socio-professional networks: having evolved within mixed networks, composed of peers and organizations associated with both organic and 'conventional' agriculture, this type of farmer now restricts his relationships within the framework of organic or ecological farmers' groups and seeks to strengthen his links with non-agricultural actors. ${ }^{10}$

More recently, this type of farmer aims to go further than the organic farming specifications and engages in a quest for naturalist knowledge. This acquisition of new knowledge is once again built through contact with local naturalist actors. Now organized in 'networks', farmers and naturalists are in contact for many projects (LPO refuge, contact with scientists, hosting trainees), which helps the acquisition of naturalistic knowledge.

The weight of the farming family and the education system explains the appropriation of traditional professional knowledge, from which one would have to extract oneself to engage in agro-ecology. It is his militant commitment and local interaction with non-agricultural actors that make it possible for this type of farmer to change practices (conversion) and build 'agrosystemic' knowledge. While still attached to the professional sphere, he is now organized around a 'peasant farming' community. Finally, it is the quest for naturalist knowledge, built through regular interactions with members of environmental associations, that completes the transition to agro-ecology.

\section{The 'Producer under environmental contract ${ }^{\prime 11}$}

This type of farmer is interested in the varieties and species grown or bred on his farm to achieve productive objectives but does not integrate ecological processes into his reasoning. He experiences a link to nature through his work, where he applies local, traditional and cultural skills. At the same time, he does not see his relationship with nature in an ideological way but rather as specified in the contracted measure.

For farmers in this category, agriculture helps to maintain open spaces and ensures the ecological vocation of the sites (counteracting the development of cereal growing

\footnotetext{
${ }^{10}$ Four of the five farmers associated with this type, settled in the $1980 \mathrm{~s}-1990 \mathrm{~s}$. After this generation of farmers, would follow their children, heirs not of intensive agriculture but of agroecology. Their commitment to agroecology is therefore seen as an obvious choice. A young farmer interviewee therefore settled directly into agro-ecology, mastered the techniques associated with it and quickly integrated his father's socioprofessional (local) networks.

${ }^{11}$ Three surveys are associated with this type.
} 
and poplar plantations). The farming profession is experienced as being in crisis: the farmer conceives agri-environmental schemes as policies that divert public authorities from their mission of supporting livestock farming. For this reason, and more markedly than for other categories, the place given to biodiversity preservation actions in their agricultural activity is made through monetary exchanges (subsidies linked to the contracted measure). They perceive this 'agricultural service' as a loss, or potential loss, of income that should be compensated. The place of biodiversity conservation in their agricultural activity is therefore only half integrated into their conceptions of the profession.

This farmer has professional knowledge of 'machine-related techniques'-i.e. he knows which agricultural techniques and equipment are suitable for which biodiversity preservation objectives. ${ }^{12}$ This knowledge is localized and limited to the requirements specified in the contracted measure. This type of farmer presents a 'superficial' understanding of environmental knowledge, as his knowledge is most often limited to the species targeted in the contents of agri-environmental programs. These are often 'umbrella' species and this farmer type does not master the broader issues related to them.

You find out that, when you harvest, you're doing pretty much the same thing. You go around, you make a gap, you spread it out and then... It doesn't really make any difference. It's not that complicated... (farmer, 55 years old, Anjou)

Biodiversity, the environment, yes, we have to take it into account. The protection of the corncrake and other things... because apparently there are other animals, even birds... (farmer, 55 years old, Anjou)

This institutional and domestic relationship to biodiversity can be explained in the 'producer under environmental contract's' socio-professional path. This son of a farmer decides to take over the family farm after his studies, or professional experience as a farm worker, associated on a collective farm with members of his family (parents, brothers and sisters, but not spouses). The family farm is involved in agrienvironmental issues, even before he takes over, through the first contracted schemes proposed by Europe at the end of the 1990s. He is therefore heir to his family's professional knowledge and does not feel the need to change. This domestic relationship marks his relationship with nature.

The difficulties that this type of farmer has to overcome are mainly economic: he has to develop new outlets to limit his dependence on agri-environmental support. In the Anjou region, this is reflected, for example, through collaboration with the LPO and the Chamber of Agriculture for the commercial development of his work in favour of biodiversity. This corresponds to the creation of the association of Anjou valley breeders, which marks the choice of integration into new sectors. Meetings with local actors take the form of debates, in which farmers and naturalists take part, or negotiations with actors in other sectors (butchers, distributors). This configuration is made

\footnotetext{
${ }^{12}$ It could be 'gentle mowing', a centrifugal mowing technique (going from the centre to the periphery), or equipment with scaring bars allowing animals to escape and join a refuge area.
} 
possible by a tradition of dialogue between the farmer, his family, the Chamber of Agriculture and the LPO.

The work of the LPO, which offers technical support (joint purchase of equipment such as scare bars) coupled with naturalist expertise (surveys, monitoring), is important to spread techniques and equipment that preserve biodiversity and to objectify the impact of agricultural practices on biodiversity. In other words, the work of the LPO allows the farmer to acquire professional technical knowledge specific to biodiversity preservation (machinery) and enables him to move from individual perceptions to shared conceptions (Bessy and Chateauraynaud 1995) to better understand the issue (naturalism). Through these interactions, farmers are led to adjust their conceptions of the profession and combine different categories of knowledge.

However, environmentalist (naturalist and ecologist type) knowledge of agro-ecology, encountered through contact with LPO actors, is still perceived as threatening by this type of farmer, who sees it as a criticism of professional legitimacy and a limitation of his decision-making autonomy. This is why his access to territorial networks of nonprofessionals remains limited. Similarly, he considers that the farmer's primary professional qualification is to produce and not to sell. He does not, therefore, automatically connect his work with consumers (for example, this type of farmer is rarely involved in direct sales). In conclusion, this type of farmer remains convinced that agriculture is a professional world 'apart', whose singularity cannot be grasped by non-agricultural actors. In parallel to their desire to remain distant from non-agricultural individuals, this type of farmer gives relatively significant weight to professional networks: advisors from professional agricultural organizations are often called upon to support strategic choices (growth, quality). The predominance of professional space in this type of path and the prevalence of the productive dimension in the occupational conception explains the distribution of tasks and skills with environmental actors, which are mainly concerned with the ecological efficiency of agricultural equipment and techniques.

For this type of farmer, non-agricultural actors are traditionally present along the career path. The interactions that take place with environmental actors around specific applications allow the appropriation of new professional knowledge or even naturalist knowledge. However, the scope of these interactions is limited by conceptions of the profession or the 'exceptionality' of the farming profession and a crisis of legitimacy. This explains why environmentalist knowledge remains substantially limited to the plot of land engaged by agri-environmental measures and to species concerned by the preservation programme.

\section{The 'neo-rural farmer'13}

This category of farmer's relationship with nature has not yet stabilized. His conception of the place given to the protection of biodiversity in agriculture is changing: depending on the situation he may draw on either environmental or professional knowledge.

I'm not one to use a word I've just learned. In other words, those who don't have a clue often speak too much... So I don't feel that I'm well enough versed on the subject yet, to be able to say 'biodiversity' here and there. I prefer to talk about

\footnotetext{
$\overline{13}$ Two surveys are associated with this type.
} 
what I know. [...] Now, as I was saying earlier, you can make a complete mistake, by meaning well, you can completely lose your head. So, I don't dare. (farmer, 45 years old, Marais Breton Vendéen)

This acquisition of agro-ecological knowledge is rooted in specific paths. This type of farmer has no farming relatives. He studies crafts. After several years as an employee, he decides to change jobs, before the age of forty, and joins the agricultural sector. He has to acquire an agricultural diploma in order to be eligible for agricultural aid. He chooses a one-year training and has multiple experiences on farms, learning agricultural techniques and how to run a production workshop. Once this first test is over, setting up remains an 'obstacle course': it is difficult for him to gain access to the land and buildings needed to start his activity. Because of his profile as an 'outsider' of the agricultural world, the 'neo-rural farmer' has little knowledge of how the professional institutions function and no network within this environment that could facilitate his installation.

On the other hand, he knows how to identify and mobilize associations that support installation projects. Naturalist associations (LPO) and 'hybrid' associations mixing agricultural and non-agricultural actors - such as the 'Coopérative d'Installation en Agriculture Paysanne' (CIAP) or 'Terre de Liens' - are mobilized. Together, these actors help by orchestrating local support groups (inhabitants, consumers, locally elected officials and farmers) or setting up a citizen's savings fund, enabling the acquisition of capital (processing equipment, buildings, agricultural land). Unlike farmers in other categories, the 'neo-rural farmer' sets up under the legal status of sole proprietorship. While his spouse may eventually consider joining him on the farm, the income she brings in through her work outside the farm provides some security.

He moves from a civic experience of human-nature relations to a professional experience, where he may be led to conceptualize interdependencies that he had not previously experienced. Consequently, the territorial stakeholders who assisted his establishment play a fundamental role in the learning process: they bring environmental and professional knowledge on agrosystems that will subsequently shape his occupational conceptions, and more particularly the place reserved for biodiversity.

This type of farmer also has the particularity of working alongside mixed professional networks: alongside the hybrid collectives mentioned above, he feels the need to ensure local anchoring ('conventional' farmers, hunters) and traditional technical monitoring to avoid 'professional errors'. Similarly, he seems to oscillate between the very critical discourse of traditional agricultural institutions and the trust he places in his technician, his path of assisted integration (training, assistance ... ) or the meaning of organic certification. This double belonging leads him, through the knowledge he gains from different spheres, to build his own ways of seeing and doing. For example, farmers belonging to this category tend to use the argument of 'doing a good job' to delay naturalist injunctions to preserve biodiversity in the wild (e.g. hedge maintenance). This search for integration into local networks seems to be linked, on the one hand, to the fact that he considers himself a novice and is looking for dialogue to extend professional learning. On the other hand, his initial professional socialization in the craft industry seems to lead him to conceive professionals as 'bridges' between the members of a local community. 


\section{Discussion}

\section{From the hypothesis of a common background of conceptions to the observation of heterogeneous models}

This research targeted a selected population of farmers engaged in preserving biodiversity, and moreover, associated with the same ecological association (the LPO). We had agreed to contribute to a definition of what it means to be a 'Farmer of Nature', and the results of the project were to be promoted in the form of an exhibition bearing this title. We then hypothesized that the survey would lead us to describe a large number of common traits within this singular population, forming the framework of a specific professional model.

We identify four occupational conceptions that differ mainly in terms of the ways in which biodiversity is interpreted (entities taken into account and knowledge used), the issues and objectives they set for themselves as farmers, and their vision of the desirable position of farmers in local social, professional and institutional situations. So, while the objective of preserving biodiversity through the practice of agriculture is indeed present for all these producers, it takes quite different forms according to these four occupational conceptions. While for some, the management of ecological spaces is at the heart of the professional project, others give this ambition a more secondary place. While some guarantee the conservation of exceptional ecosystems, others seek to mobilize ecological processes for productive purposes.

These conceptions are associated with specific and differentiated knowledge. We identify two main categories of knowledge that allow us to address the links between agriculture and biodiversity: environmentalist (naturalist, ecologist) and professional knowledge (agrosystem, machinery). Farmers engaged in an agro-ecological approach may have to combine different forms of knowledge: scientific and practical, with ecological, naturalist and agronomic sciences often being called upon in exchanges between these farmers. Each occupational conception, and in particular of the relationship between agriculture and biodiversity, is associated with a singular combination of knowledge. Moreover, we show that most farmers we met are part of a dynamic process of knowledge production in which local networks play a decisive role. We will return to this point.

Finally, this is articulated with different conceptions of their roles and the contours of the professional worlds (in the sense of (Becker 1951)) within which they work. While 'protectors of natural areas' develop their activity by collaborating with various actors outside the professional sector (local authorities, naturalists) and by addressing a wide variety of clients through educational and direct sales activities, 'producers under environmental contracts' see their role as strictly food production, and limit their interactions to within the 'agricultural social environment'.

Our work reinforces the results of various studies that describe the diversity of models within agro-ecology. In particular, we highlight the diversity of the relationships of these farmers to professional and local institutions, as well as their de facto integration into food systems. While some call for food systems to be redesigned based on links with local consumers and various forms of cooperation between farmers and territorial actors (the case of 'protectors of natural areas' and 'neo-rural farmers'), others are dealing with longer chains, backed by established labels (Organic) (this is 
the case of 'producers under environmental contracts' and 'dissident farmers'). Our work leads us to qualify the links between the farmer's socio-territorial integration and their contributions to biodiversity: the redesign of territorialized food systems does not necessarily appear to be a deepening of the greening of agriculture. The case of "neorural farmers' illustrates this: setting up in agriculture is based on a structuring project of territorial anchoring, but does demonstrate a relationship, however distant, with agro-ecology.

\section{Process of selecting and hybridizing conceptions during socio-professional paths}

This diversity of job conceptions is largely explained through the diversity of the social paths of the farmers surveyed. These paths are the seat of a dual process of selection and learning that contribute to the progressive construction of the forms of professionalism at work today.

We propose first of all that farmers in the profession today have overcome a certain number of challenges. Indeed, access to the farming profession is a selective process. In the region we are interested in, over the recent period (2014-2016), on average 1450 'candidates' for installation contacted the agents at the regional Chamber of Agriculture's installation reception point. Eighty percent of them wanted to apply for installation aid, but only 500 people actually settle with the aid each year and just as many farmers settle outside this system. ${ }^{14}$ Even though most farmers develop long careers, each year a third stop their activity early (before the age of 55) (Allaire and Maigné 2017). Our research shows that this population of farmers faces a variety of challenges, at the time of setting up and during their career, related to access to land and the possibility of investing at the time of setting up, the development of marketing channels, the development of new professional networks and the separation from old networks. Interactions with actors outside the professional agricultural sphere provide important social resources to overcome these challenges. Non-agricultural actors therefore participate in making ecological farming projects possible and as such contribute to a certain diversification of ways of practising and conceiving agriculture. Secondly, this support contributes to the constitution of heterogeneous local mutual aid and exchange networks, which participate in training producers. They also contribute to shaping conceptions of desirable and possible relations between farmers and local actors.

These results lead us to nuance the weight of the farming family on the selection of heirs and constructing occupational conceptions and professional knowledge. While for 'producers under environmental contracts', and probably for the children of 'dissident farmers', this weight remains important. For most of the farmers we met, family plays a minor role in the transmission of the trade. First of all, local organizations act as a counterweight to the selection processes that take place within farming families, by opening the possibility of setting up to new entrants without the presumed dispositions of farmers' children (Jacques-Jouvenot and Gillet 2001). Secondly, while the family remains a space where vocations are created (Bessière 2010), sons of farmers often disassociate with farming knowledge inherited from childhood.

\footnotetext{
${ }^{14}$ Statistics from the regional transmission installation observatory produced by the Pays de la Loire Chamber of Agriculture from 2014 to 2017.
} 
Several works highlight the diversity and evolution of knowledge production in contemporary farming or agro-ecological movements. In particular, some authors stress the importance of active processes of experimentation and knowledge accessed by farmers, of renewed relationships with research or development actors outside the traditional technicoscientific devices of the agricultural profession, emerging forms that deal with more traditional processes of knowledge production among peers. Here, on the other hand, we underline the decisive role of expert knowledge (naturalist and ecological), acquired during schooling and sometimes through professional experience in naturalist organizations. In these local arenas, this knowledge is carried by farmers with singular socio-professional paths (protectors of natural areas) and by nonagricultural actors (LPO naturalists). Promoted in this local, social space, these actors actively contribute to a process of knowledge dissemination among their peers.

It therefore appears, congruently with a wide spectrum of literature, that the role of local socio-professional networks is decisive in the processes of circulation and knowledge and the construction of professional models (Bernard et al. 2005; Candau and Ruault 2005; Compagnone and Hellec 2015; Demeulenaere and Bonneuil 2010; Le Guen and Sigwalt 1999; Ruault and Soulard 2015). Our work has the originality of proposing a current and retrospective analysis of the social configurations that shape the dynamics of knowledge construction. For farmers, themselves children of farmers, two types of knowledge construction processes appear. In some cases, an early and/or prolonged socialization with territorial actors (in the cases studied, naturalists and militant consumer movements) tends to shape a conception of agriculture at the service of biodiversity and to lead to the construction of environmentalist or 'ecological' professional knowledge (here called agrosystemic). In other cases, local family and professional socialization traditionally allows access to territorial actors and longstanding inclusion in established agro-environmental systems contributes to basic naturalist knowledge on agro-ecology, above all based on a technical professional base, linked to machinery. In these cases, environmentalist knowledge triggers a process of 're-literating nature' (Deschamps and Demeulenaere 2015) which authorizes the commitment to an agro-ecological approach. Moreover, since nearly half of the farmers in our survey do not come from farming families, the roles of schools and of militant and professional networks appear to play an important role in the processes of knowledge construction and dissemination among this population.

\section{A local dynamic of prioritization: how to be a good farmer according to the LPO}

Our research also points to the asymmetric and hierarchical nature of learning processes. The encounter between environmental and professional knowledge takes place through interactions between farmers and non-agricultural actors, but also through farmers themselves. Certain categories of ecological farmers ('protector of natural areas', 'dissident farmers' and 'neo-rural farmers') are found in the same group'Farmers of Nature' - led by the LPO. This collective, bringing farmers and environmental actors together, is a place where farmers can carry out cross-learning and an important resource in moving towards agro-ecology. This learning is asymmetrical: 'dissident farmers' and 'neo-rural farmers' turn to 'protectors of natural area' and naturalist facilitators to improve their environmental knowledge. This process is part of an evolution in practices and a shared project to maintain a leading role in the 
definition sustainable agriculture, when organic agriculture, according to them, is engaged in a process of conventionalization (Teil 2014).

Through these knowledge dynamics, the social construction of a model of ecological farming is also at stake. In fact, the LPO association also has a decisive role in the elaboration of a local hierarchy between ways of practising agro-ecology. The association tends to promote a certain model of farmer: the 'protectors of natural areas' and participates in a devaluation of empirical farming knowledge of farmers in favour of environmentalist knowledge, presupposing the superiority of the latter in the preservation of biodiversity, without any real scientific objectification. This can be seen both in the discourse on agro-ecology of LPO employees and in the fact that 'natural area managers' have leadership roles in local associations (LPOs, but also producer or consumer associations). The other members of the network would therefore need to catch up.

\section{What this research tells us about the processes of defining agro-ecology}

Within this group of 'Farmers of Nature', we show how socio-professional paths contribute to the shaping of singular professional models through a double process of learning and selection. The dynamics of job conceptions relies on a variety of processes, ranging from ruptures based on opposition to a dominant occupational reference framework, to more continuous or iterative processes, where the farmer reorganizes his knowledge based on a panel of knowledge and, ultimately, renegotiates his professional identity. This is what Deschamps and Demeulenaere (2015) describe: a farmer puts aside knowledge relating to 'modernity' — which does not provide him with the necessary keys for understanding biodiversity - and seeks to reconnect with forgotten knowledge, residing in a 'contemplative', 'curious' and holistic understanding of biodiversity. Our research also points to the decisive role of the transmission of expert knowledge (naturalists and ecologists) via schools, initial professional experiences or via social processes of knowledge transmission within heterogeneous local networks. In addition, the farmers we met all went through hardships at the time of setting up and then during their careers. In order to overcome them, they forged solid networks, support and cooperation, structuring a local social world that shapes some of their occupational conceptions. In one of the territories, the agricultural profession plays a decisive role in supporting farmers during these trials (via sectorial development, assistance in setting up and the promotion of administrative support systems such as the agri-environmental measures). In Vendée, those participating alongside farmers are mostly non-agricultural actors (naturalist association, local authorities, citizen associations for the establishment of farmers, for access to land, the development of local markets or the transmission of knowledge). These organizations then support farmers and promote an agro-ecological model based on the withdrawal of agricultural activities from the ecosystem and a certain vision of territorial governance for the transition (implying, in particular, a commitment to local social networks of consumers and naturalists and a certain distance from conventional professional institutions). In this way, they participate, from 'outside', towards competition between professional models by seeking to define and promote a form of agro-ecology around the 'Farmers of Nature'. 
Code availability Not applicable.

Authors' contributions Bertille Thareau directed the research and contributed to the article writing. Clara Pailleux did the fieldwork and contributed to the writing. Guilhem Anzalone contributed to the research and writing.

Funding information This article presents the results of the research project 'Preserving biodiversity and producing food goods: analysis of the development conditions, functioning and ecological and socioeconomic effects of non-institutionalised territorial approaches in Pays de la Loire', in response the BEAUTOUR call for projects (Biodiversity, Ecosystem, Agriculture, Town planning, Territory: a Work and Union Tool for Research). This project was funded by Pays de la Loire Region and piloted by the LPO Pays de la Loire.

Data availability The data are verbatim of interviews. Given the monographic nature of the research, the interviews cannot be anonymized. The data are therefore not available.

\section{Compliance with ethical standards}

Conflict of interest Authors and one of the major actors cited in this article - LPO - were partners in this project. The implications of this situation are developed in the present article.

\section{References}

Allaire, G., \& Maigné, É. (2017). Carrières d'agriculteurs et transformation des structures des exploitations agricoles. Economie Rurale, 357(1), 123-144.

Barbier M. and Lemery B. (2000). Learning through processes of change in agriculture: a methodological framework, in: Cerf, M., Gibbon, D., Bernard, H., Jiggins, J., Ison, R., Paine, M., Proost, J. and Röling, N. (éds.), Cow up a Tree: Knowing and Learning for Change in Agriculture. Case Studies from industrialized countries, (pp. 381-393), INRA Editions.

Becker, H. S. (1951). The professional dance musician and his audience. American Journal of Sociology, 57, 136-144.

Bernard, C., Dufour, A., \& Angelucci, M.-A. (2005). L'agriculture périurbaine : interactions sociales et renouvellement du métier d'agriculteur. Economie rurale, 288, 70-85.

Bertaux D. (1997). Les récits de vie : perspective ethnosociologique, Nathan, 127 p.

Bessière, C. (2010). De génération en génération. Arrangements de famille dans les entreprises viticoles de Cognac. Paris : Raison d'Agir.

Bessy, C., \& Chateauraynaud, F. (1995). Experts et faussaires. Pour une sociologie de la perception. Paris: Métailié 368 p.

Bidart, C., Longo, M. E., \& Mendez, A. (2013). Time and process: an operational framework for processual analysis. European Sociological Review, 29(4), 743-751.

Bourdieu, P. (1986). L'illusion biographique. Actes de La Recherche En Sciences Sociales, 62-63, 69-72.

Candau, J., \& Ruault, C. (2005). Evolution des modèles professionnels en agriculture : scènes de débat, questions d'écologie et catégories de connaissances. Cahiers d'économie et sociologie rurales, 75, 52-74.

Cayre, P., Michaud, A., Theau, J.-P., \& Rigolot, C. (2018). The coexistence of multiple worldviews in livestock farming drives agroecological transition. A case study in French Protected Designation of Origin (PDO) cheese mountain areas. Sustainability, 10(4), 1097.

Chaxel, S., Fiorelli, C., \& Moity-Maïzi, P. (2014). Les récits de vie : outils pour la compréhension et catalyseurs pour l'action. Interrogations, 17, 1-13.

Compagnone, C., \& Hellec, F. (2015). Farmers' professional dialogue networks and dynamics of change: the case of ICP and no-tillage adoption in Burgundy (France). Rural Sociology, 80(2), 248-273. 
Demeulenaere E. and Bonneuil C. (2010). Cultiver la biodiversité. Semences et identité paysanne. In : Hervieu, B., Mayer, N., Muller, P., Purseigle and F., Rémy, J. (eds), Les mondes agricoles en politique. De la fin des paysans au retour de la question agricole, pp. 73-92.

Deschamps, S., \& Demeulenaere, E. (2015). L'observatoire agricole de la biodiversité. Vers un ré-ancrage des pratiques dans leur milieu. Etudes rurales, 195(1), 109-126.

Dubar, C., Tripier, P., \& Boussard, V. (2015). Sociologie des professions. Paris: Armand Colinp.

Dubuisson-Quellier S. and Giraud C. (2010) Les agriculteurs entre clôtures et passerelles., in: Les mondes agricoles en politique. De la fin des paysans au retour de la question agricole., Hervieu, B. et al. (éds.), Presses de Sciences Po, 111-129.

Dufour, A., Mauz, I., Rémy, J., Bernard, C., Dobremez, L., Havet, A., Pauthenet, Y., Pluvinage, J., \& Tchakérian, E. (2007). Multifunctionality in agriculture and its agents: regional comparisons. Sociologia Ruralis, 47(4), 316-342.

Dufour, A., Alavoine-Mornas, F., Godet, J., \& Madelrieux, S. (2016). Diversité des cheminements en agriculture biologique: le sens du métier en question? Innovations Agronomiques, 51, 19-28.

Goulet, F., \& Vinck, D. (2012). L'innovation par retrait. Contribution à une sociologie du détachement. Revue Française de Sociologie, 53(2), 195-224.

Hedlund-de Witt, A. (2013). Worldviews and their significance for the global sustainable development debate. Environmental Ethics, 35(2), 133-162.

Hervieu, B., \& Purseigle, F. (2015). The sociology of agricultural worlds: from a sociology of change to a sociology of coexistence. Review of agricultural and environmental studies, 96(1), 59-90.

Jacques-Jouvenot, D., \& Gillet, M. (2001). L'agriculture en Franche-Comté : Un Métier Patrimonial Rediscuté. Etudes rurales, 159-160(3), 111-128.

Joosse, S., \& Grubbström, A. (2017). Continuity in farming - not just family business. Journal of Rural Studies, 50, 198-208.

Lamine, C. (2011). Transition pathways towards a robust ecologization of agriculture and the need for system redesign. Cases from organic farming and IPM. Journal of Rural Studies, 27(2), 209-219.

Le Guen, R., \& Sigwalt, A. (1999). Le métier d'éleveur face à une politique de protection de la bio-diversité. Economie rurale, 249, 41-48.

Micoud, A. (2005). La biodiversité est-elle encore naturelle ? Ecologie \& politique, 30(1), 17-25.

Pibou, E. (2013). Entre continuités et discontinuités : examen des parcours des fermier-e-s de Terre de liens. Pour, 220(4), 217-226.

Plumecocq, G., Debril, T., Duru, M., Magrini, M.-B., Sarthou, J., \& Therond, O. (2018). The plurality of values in sustainable agriculture models: diverse lock-in and coevolution patterns. Ecology and Society, 23(1).

Ruault C. \& Soulard C. (2015). Permanence et renouveau des collectifs en agriculture et dans le développement. L'actualité de la pensée de Jean Pierre Darré. Colloque Hommage À Jean-Pierre Darré, 9 septembre, Dijon, pp. 1-10.

Teil G. (2014). Is organic farming unsustainable? An analysis of the debate about the conventionalisation of the organic label., In: Bellon, S. and Penvern, S. (éds.), Organic farming, prototype for agricultures, Springer, Berlin, pp. 325-344.

Thareau, B., Couvreur, S., Manoli, C., Pithon-Rivallain, J., Pain, G., \& Di Bianco, S. (2016). Competing socio-technical transition pathways towards implementation of conservation policy aimed at enhancing hedgerow and grassland networks. In A. Wilcox \& K. Mills (Eds.), 12th European IFSA Symposium, Harper Adams University (Vol. 1, pp. 750-761).

Van Dam, D. (2005). Les agriculteurs bio, vocation ou intérêt? Namur: Presses Universitaires de Namur 204 p.

Wezel, A., \& Peeters, A. (2014). Agroecology and herbivore farming systems-principles and practices. Options Méditerranéennes, 109, 753-768.

Publisher's note Springer Nature remains neutral with regard to jurisdictional claims in published maps and institutional affiliations. 